\title{
Assessment of Open Burning of Agricultural Wastein Biu Local Government Area of Borno State, Nigeria
}

\author{
Mamman, $\mathbf{M}$. \\ Geography Department, Ahmadu Bello University, Zaria \\ Folorunsho, J. O. (Ph.D) \\ Geography Department, Federal University, Lokoja, Kogi State
}

\begin{abstract}
Assessment of potential open burning of agricultural crop residue of post-harvest waste generations in Biu local government areas of Borno State, Nigeria was estimated. This is with a view of knowing the types, quantity and strength of these crop residues generated annually in the study area. The method adopted was field survey and focused group discussion of and the result collected. The total hectares of land cultivated for the major crop selected from the host communities were estimated to be 1450ha. in the year under study. From the study, maize, millet and rice are being produced in large quantity in the place visited. For maize alone in ten communities, 140 tonnes of waste is produced, 118 tonnes of sorghum, 115 tonnes of millet, 111 tonnes of rice and 53 tonnes of cowpea waste is produced. The major management measure adopted is burning which is not environmentally friendly. The annual quantity of agricultural crop residues generated for burning in these communities is estimated to be 381 tons. Among the entire communities selected, Maina Hari has the highest hectares of land cultivated during the period of field survey followed by Mangada and Mandafuma. The survey also revealed that farmers have difficulties in accessing information on environmental health hazard of open burning of agricultural waste. While some even lack any knowledge about health risk of burning crops residue, apart from increasing soil fertility to their farm and also facilitate land clearing prior to raining season. Regulatory efforts should focus on the identification and control of environmental airborne sources of pollution resulting from burning activities, which are currently the major origin of food chain contamination.
\end{abstract}

Keywords: crop residue, environmental health hazard, open burning, post-harvest, waste,

\section{INTRODUCTION}

Wastes are materials that are not prime products (that products produced for the market) for which the initial user has no purpose of production, transformation or consumption, and of which the user wants to dispose. Waste may be generated during the extraction of raw materials, the processing of raw materials, into intermediate and final products, the consumption of final products, and other human activities, (UNSD, 1997). Miller (1980) defined waste as "substances and materials that are disposed of according to the provision of natural law". Zero waste America (2003) also defines waste as "a resource that is not safely recycled back into the environment or market place". Waste (residue, trash, refuse, garbage, Junk or litter) is an unwanted or useless material (ISWA and UNEP, 2002). The compositions of different wastes have varied over time and location, with industrial development and innovation being directly linked to waste materials. There are three types of waste which include; solid, liquid and gas, these waste are also classified into various category, which are industrial, domestic, commercial, institutional, and agricultural wastes. 
Agricultural waste, which includes both natural (organic) and non-organic materials, is a general term used to describe waste produced on a farm through various farming activities. These activities can include but are not limited to dairy farming, horticulture, seed growing, livestock breeding, grazing land, market gardens, nursery plots, and even woodlands (Nix, 2002).The by-products of agricultural activities are usually referred to as "agricultural waste" because they are not the primary products. These wastes chiefly take the form of crop residues (residual stalks, straw, leaves, roots, husks, shells etc.) and animal waste (manures). Agricultural wastes are widely available, renewable and virtually free, hence they can be an important resource (Sabiiti, 2005). They can be converted into heat, steam, charcoal, methanol, ethanol, bio diesel as well as raw materials (animal feed, composting, energy, and biogas construction).

Open burning of agricultural residues is an inexpensive means to advance crop rotation and control insects, disease, and the emergence of invasive weed species. While the economic and practical benefits of burning agricultural residues are apparent, the environmental and health risks of this activity need to be fairly recognized (Bamidele, 1998; Nilanthi, Badara and Patrick, 2010).Burning of agricultural residues also emits polychlorinated dibenzo-p-dioxins (PCDDs), and polychlorinated dibenzofurans (PCDFs), because of the presence of Chlorine in the residue (USEPA, 2000). In particular, open burning usually occurs at low temperatures of $250-450{ }^{\circ} \mathrm{C}$ and in uncontrolled conditions, which are favorable for forming incomplete combustion products, and, thus, more PCDD/Fs are emitted than those from high-temperature and wellcontrolled burnings. Dioxins and furans (PCDD/PCDF) are formed during incomplete combustion of organic material where chlorine is available in the feedstock or in the air supply during the combustion process, and they are also produced as trace contaminants in various industrial processes (USEPA, 2000).

In developed countries, intentional open burning of wastes is strictly controlled and has long been considered as an outdated technology. The numerous studies pointing to open burning as a major source of hazardous emissions prompted these countries to impose stringent restrictions on these activities, among the groups of noxious gaseous emissions from open burning are polychlorinated dibenzo-p-dioxins (PCDDs), polychlorinated dibenzofurans (PCDFs), volatile organic carbons (VOC), semi-volatile organic carbons (SVOC), carbonyls, and chlorobenzenes (Andreae and Merlet, 2001).With the entry of the Stockholm Convention into force, concerns have been focused by various countries on polychlorinated dibenzo-p-dioxins (PCDDs) and polychlorinated dibenzofurans (PCDFs) as these are known toxic products of incomplete and less than ideal combustion conditions (Costner, 2005). To meet their obligations to the Convention and in response to the national regulatory measures imposed, developed countries have applied the best available techniques and effectively abated some toxic emissions particularly in the incineration of municipal solid wastes.

Shaban, Hussein, Abou, and Omaima, (2010), examine the utilization of agricultural waste as one of the environmental issues in Egypt. Agricultural wastes generated in Egypt range from 30-35 million tons a year of which only 7 million tons as animal feed and 4 million as organic manure are being utilized. The problem of agriculture wastes becomes very obvious and aggregated after the harvest of summer crops. That is because at this time of the season, the farmer is in a rush to re-cultivate his land therefore getting rid of the wastes has his highest priorities, usually by burning. This method, burning not only is considered an economic loss but also has harmful effects on the environment. 
Therefore, the finding is that utilization of agriculture wastes in any other environmentally friendly way is very important; these can be done by either Compost production by fermenting the agricultural waste in the main way for recycling which will help in re-fertilizing the soil organically and reduce the production cost of fertilizer, Animal feed production by treating some wastes such as rice straw by Urea or ammonia to increase its nitrogen content to hence its nutritional value, Food production, this can be done by growing mushroom on agricultural wastes such as rice straw as a substrate. This means the conversion of wastes to economic, nutritional human food, Growing vegetables on rice straw compacted bales in areas where soil disease and salinity are constrains, Energy production such as Bio gas, it can be concluded that recycling agriculture wastes is a must for environment as well as economical saving. This recycling will not only increase agricultural production but also will improve its quality.

John (2011) on agricultural and forestry wastes and their opportunities for use as an Energy Source in Nigeria examined the uses of agricultural residues, their conversion routes and utilization systems. Various agricultural and forestry biomass convertible to energy products were identified. The study highlighted the benefits to be derived from the use of agricultural and forestry residues as energy source in Nigeria, using Gasification, Bio-gasification, Liquefaction, Briquetting Process and Composting. The research suggested that all the techniques of conversion discussed could form an agricultural complex utilizing briquettes as a renewable energy source; using anaerobic digestion (biogas) to produce energy and fertilizer; composting for soil conditioner; pyrolysis to produce medium grade fuels and chemical preservatives and production of animal fodder through the process of pelletizing. The study concluded that, finding practical and economic uses for the agricultural and forestry residues will create an opportunity to build a bio economy which will deliver sustainable economic growth with job creation and social cohesion as key outcomes.

To the best of the researchers' knowledge and based on accessible literature Adeoye, Adebayo, and Musa, 2011; Shaban, Hussein, Abou, and Omaima, 2010; John, 2011 and Kwagheet al., 2011, there is no research carried out on the assessment of potential open burning of agricultural crop residues generated on major crops grown in Biu local government area of Borno State. Also Biu like any other northern Nigerian society is agrarian where several tons of agricultural crop residues are either misused or left unused. For these reasons, therefore, this study intends to fill gap in knowledge about the assessment of potential open burning of agricultural crop residues in the study area. The study estimates the potential open burning of agricultural crop residues in Biu local government area (LGA) of Borno State. The specific objectives are to assess the hectares of land under different crop types in the study area, quantify (tons) of agricultural crop residues generated per crop type in study area and examine the different mechanism of disposing agricultural residues

\section{STUDY AREA}

Biu Local Government area is located in the north eastern part of Nigeria, bounded on the west by the Gongola River valley, on the southwest by the Hawul River valley and on the north by the Lake Chad basin (Online Nigeria, 2003). It is located in the Sahel savannah and covers 5,200sq.km. Biu Local Government lies between latitude $10^{\circ} 36^{\prime} 40^{\prime \prime} \mathrm{N}$ and $10^{\circ} 61^{\prime} 11^{\circ} \mathrm{N}$ and longitude $12^{\circ} 11^{\prime} 42^{\prime \prime} \mathrm{E}$ and $12^{\circ} 19^{\prime} 5^{\circ} \mathrm{E}$, because of the broad geographical extent, its physical setting is bound to be varied. The Biu Plateau is a highland area in south eastern Nigeria containing many recently extinct volcanoes. It covers about 5,200 $\mathrm{km} 2(2,000 \mathrm{sq} \mathrm{mi})$ and has an average elevation of $700 \mathrm{~m}(2,300 \mathrm{ft}$.). There is evidence of early volcanic activity in the area during the Cretaceous, which ended about 66 million years ago(Taylor and Francis, 1971).Three seasons have been identified: the cool dry (harmattan) season (October-March), 
hot dry season (April-June) and rainy season (July-September). Temperatures are high all the year round, with hot season temperatures ranging between $39^{\circ} \mathrm{C}$ and $40^{\circ} \mathrm{C}$ under the shade. In the southern part of the state, the weather is relatively mild.Principal ethnic group of Biu include the Baburawa, Fulanis, Hausas and other non-indigenous groups, with population of 176,072 according to 2006, census. The Biu Local Government Area has a large number of communities in addition to Biu, which include: Balbaya, Mbulamile, Buratai, Mirnga, SabonLayi, Tum, Yamarkumi, Zara, FilinJirgi, Galdimare, Garundana, Kimba, Kogu, MainaHari, Mandafuma, Mandagirau, Mangada (Amaza, et al., 2007).It is inhabited by the indigenous Hausas and other multi-ethnic groups and the languages spoken are Hausa, Fulani, English, Igbo and Yoruba, with Hausa as the common medium of communication and English language which is the conventional means of communication (Ali, 1995). The economy of Biu local government area is mixed agricultural based on herding cattle, goats, sheep, horse and donkeys and farming activities which include; Sorghum, Rice, Maize, Cowpea and Cotton. Agriculture consists mostly of small farms using traditional methods. About $70 \%$ of the populations in the study area engage in farming.

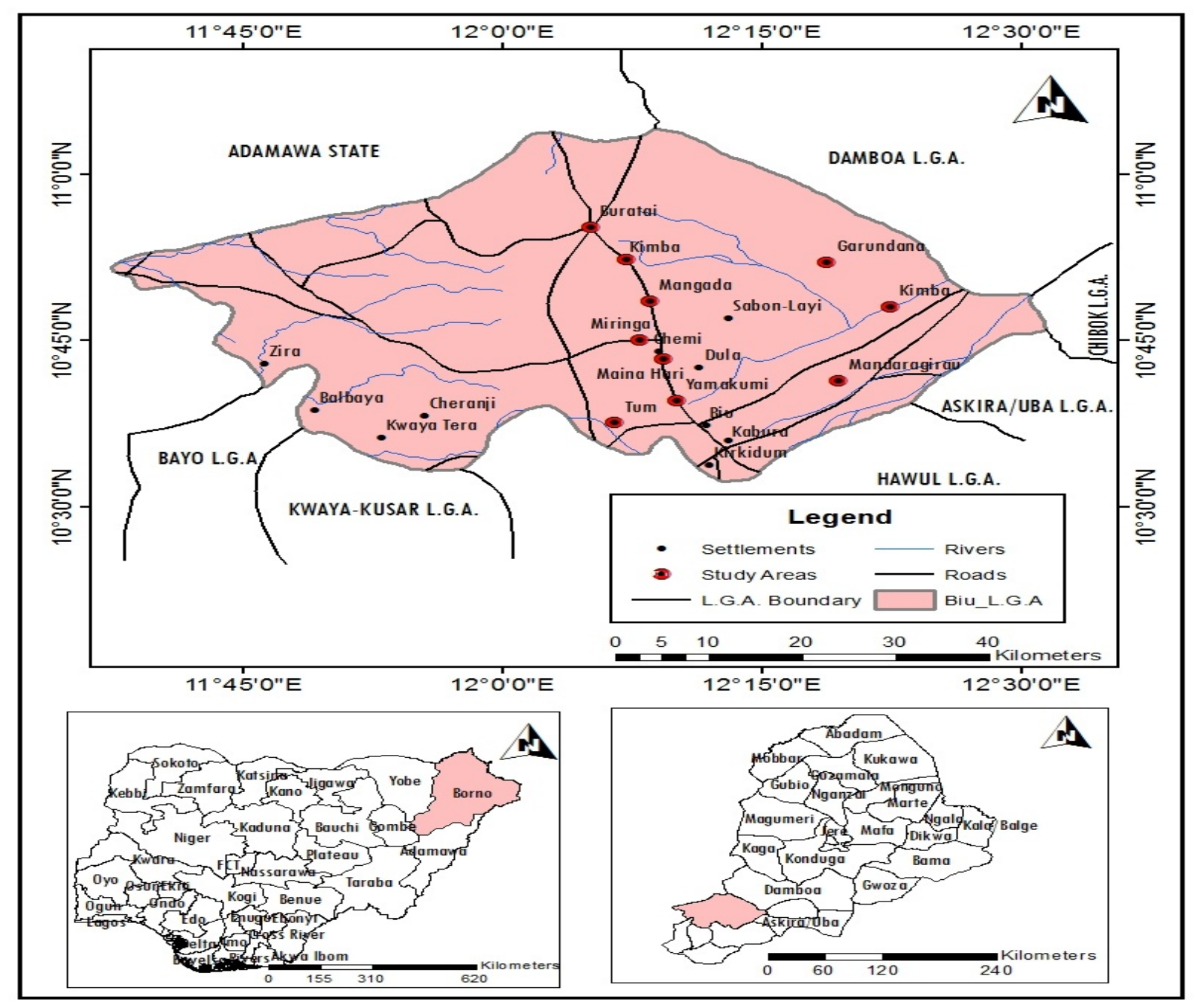

Fig. 1: Map of the Study Area

Source: Modified from the Administrative Map of Borno State.

\section{MATERIALS AND METHODS}

The research was carried out using direct field observation and on-site measurement of cultivated hectares and crops waste. The study also make use of focus group discussion (FGD) 
among the farmers in the study area with a view to gather relevant information and data in the field, and it is expected that this technique was to provide valuable information with respect tothe research under investigation. As part of the secondary source of data, international publications, journals, textbooks, conference papers, thesis and dissertation were also used. Information in the ministry of agriculture Biu local Government of area Borno state was also utilized. In selecting the communities to be sampled, purposive sampling technique was employed. This sampling technique is the most ideal in order to accommodate the varying types of agricultural crop residues (waste) in the study area. Annual mass-harvest for different crop types by defined land area; Post-harvest waste fraction of different crop types; Hectares and percentage of land used for particular crops that is subject to a burn-management regime, Weighing scale, Bags, were used.

\section{Hectares of Land and Crop Types in the Study Area}

\section{RESULTS AND DISCUSSION}

The study area is characterized by different crop types on large hectares of land. Table 1 shows the various farmyards, approximate hectares of land covered and the different crops planted. From table 1 below it can be clearly seen that Maina Hari Community has the highest hectare of cultivated land in the communities in the year under study with a total of approximately 163 hectares of cultivated lands under different crop types. Mangada Community is the second with a total land area of about 153 hectares. The major crop types cultivated in the study area are Maize, Millet, Sorghum, Rice, Cotton and Cowpea. These crops constitute the major generators of crop residues in the study area, because most farmers grow them for their food consumption and also serve as the major source of their income due to the fact that most of them are farmers. Most of the lands are hilly which makes it very difficult to farm especially during tillage and planting, but still farmers do engage in agricultural activities due to the fact that it is the major source of income generation to the communities.

Table 1: Hectares of Land and Cultivated Crops in the Study Area

\begin{tabular}{lcl}
\hline Community & $\begin{array}{c}\text { Total Area of Land } \\
\text { Cultivated } \\
\text { Per Year (Hectare) }\end{array}$ & \multicolumn{1}{c}{ Major Crops Planted } \\
\hline Miringa & 144 & Maize, millet, sorghum, rice, cotton \\
Tum & 141 & Maize, millet, sorghum, rice, cotton \\
Mandafuma & 151 & Maize, millet, sorghum, rice, cotton \\
MainaHari & 163 & Maize, millet, sorghum, rice, sugarcane \\
Buratai & 122 & Maize, millet, sorghum, rice, cowpea \\
Mandaragirau & 142 & Maize, millet, sorghum, rice, cowpea \\
Mangada & 153 & Maize, millet, sorghum, rice, cowpea \\
Kimba & 140 & Maize, millet, sorghum, rice \\
Yamarkumi & 150 & Maize, millet, sorghum, rice, cowpea \\
Garundana & 144 & Maize, millet, sorghum, rice, cowpea \\
\hline
\end{tabular}

Source: Author's Field Work, 2014

\section{Quantity of Agricultural Crop Residue Generated in the Study Area}

The quantity of agricultural crop residue is the total volume of crop waste generated from remnants obtained during harvesting, crop processing and food processing wastes in a study area (Kwaghe et al., 2011). Table 2 shows the estimated quantity (tons) of crop residue generated in the study area for a year. The total volume of agricultural crop residue generated in the study area is 564 tons from the table, it can also be seen that Mandaragirau community generated the highest quantity of agricultural crop residues with 76 tons thereby contributing 
$13.48 \%$ of the total agricultural crop residue. This is because most farming households are commercial farmers responsible for producing most of the food cropsin the study area. MainaHari and Miringa came 2nd and 3rd with $10.99 \%$ and $10.46 \%$ of agricultural crop residues respectively.

Table 2: Quantity of Agricultural Crop Residue Generated in the Study Area in a Year

\begin{tabular}{lll}
\hline Community & $\begin{array}{l}\text { Estimated Quantity } \\
\text { OfCrop Residue } \\
\text { (tons) }\end{array}$ & $\begin{array}{l}\text { Crop Residue } \\
\text { Relation } \\
\text { Community(\%) }\end{array}$ \\
& $\begin{array}{c}\text { Generated in } \\
\text { to }\end{array}$ \\
\hline Miringa & 59 & 10.46 \\
Tum & 56 & 9.93 \\
Mandafuma & 51 & 9.04 \\
MainaHari & 62 & 10.99 \\
Buratai & 47 & 8.33 \\
Mandaragirau & 76 & 13.48 \\
Mangada & 57 & 10.11 \\
Kimba & 54 & 9.57 \\
Yamarkumi & 50 & 8.87 \\
Garundana & 52 & 9.22 \\
\hline Total & $\mathbf{5 6 4}$ & $\mathbf{1 0 0}$ \\
\hline
\end{tabular}

Source: Author's Field Work, 2014

The work of Kwaghe et al, (2011) revealed that the estimated quantity or tonnage of agricultural waste for farming households in Jere Local Government area of Borno State is 264 tonnes with crops accounting to 161 tonnes of waste and animals accounting to 103 tonnes of waste. This shows that Biu local government area of Borno state generates more agricultural crop residues when compared with Jere local government area of the same state.

\section{Disposal Mechanism Adopted in the Study Area}

Agricultural biomass waste converted to energy can substantially displace fossil fuel, reduce emissions of greenhouse gases and provide renewable energy to people in the study area. There are several methods that have been developed for better disposal of agricultural residues. Agricultural crop residues (grass, dry leaves, straw, stalk, etc.) produced in huge quantities in the study area is not well utilized. The management techniques adopted in the study area are assessed subsequently.

The responses given by the farmers associations contacted on how they manage their farm wastes are presented in table 3 Burning is the predominant management option as seen in the table below. Most of the farmers practice mixed farming and they feed their livestock with the straws and stalks. This agrees with the work of El-Haggaret al (2004) where the researchers noted that despite the management options available to farmers in most rural areas, many farmers view the practice of residue utilization as an extra cost with small returns and therefore the best way is to get rid of the crop residues is by dumping, animal feed and burning etc.

Burning is also a predominant waste management option. This agrees with the work of ElHaggaret al.,(2004) where the researchers noted that despite the management options available to farmers in most rural areas, many farmers view the practice of residue utilization 
as an extra cost with small returns and therefore the best way to get rid of the residues is by dumping, open burning, etc.

Table 4 below shows that Mandaragirau generated the highest amount of crop residue subjected to a burning having about $14.96 \%$ of the total amount of waste burnt in the study area. Likewise, Miringa and Maina Hari came 2nd and 3rd with $12.36 \%$ and $11.29 \%$ respectively. This indicates that inadequate knowledge of crop residue reuse value and utilization is one of the major problems facing the people and lack of awareness on health hazards related to burning of agricultural crop residue in those communities makes it very easier for them to burnt their waste in the farm.

Table 3: Means of Disposal of Agricultural Crop Residue in the Study Area

\begin{tabular}{|c|c|c|}
\hline Community & Primary Crop Type & Means of Disposal \\
\hline \multirow[t]{3}{*}{ Miringa } & Maize, Millet, Sorghum & Burning and animal feed \\
\hline & Rice & Burning and building \\
\hline & Cotton & Burning \\
\hline \multirow{2}{*}{ Tum } & Maize, Millet, Sorghum & Burning and animal feed \\
\hline & Rice and cotton & Burning \\
\hline \multirow[t]{3}{*}{ Mandafuma } & Maize, Millet, Sorghum & Burning and animal feed \\
\hline & Rice & Burning \\
\hline & Cotton & Nil \\
\hline \multirow[t]{3}{*}{ MainaHari } & Maize, Millet, Sorghum & Burning and animal feed \\
\hline & Rice & Burning/Building \\
\hline & Sugarcane bagasse & Burning \\
\hline \multirow[t]{4}{*}{ Buratai } & Maize & Building, burning and animal feed \\
\hline & Millet and Sorghum & Burning and animal feed \\
\hline & Rice & Burning/Building \\
\hline & Cowpea & Burning \\
\hline \multirow[t]{5}{*}{ Mandaragirau } & Maize & Building, burning and animal feed \\
\hline & Millet & Burning and animal feed \\
\hline & Sorghum & Burning and animal feed \\
\hline & Rice & Burning/Building \\
\hline & Cowpea & Burning/Animal feed \\
\hline \multirow[t]{5}{*}{ Mangada } & Maize & Building, burning and animal feed \\
\hline & Millet & Burning and animal feed \\
\hline & Sorghum & Burning and animal feed \\
\hline & Rice & Burning/Building \\
\hline & Cowpea & Burning/Animal feed \\
\hline \multirow[t]{3}{*}{ Kimba } & Maize & Building, burning and animal feed \\
\hline & Millet and Sorghum & Burning and animal feed \\
\hline & Rice & Burning/Building \\
\hline \multirow[t]{4}{*}{ Yamarkumi } & Maize & Building, burning and animal feed \\
\hline & Millet and Sorghum & Burning and animal feed \\
\hline & Rice & Burning and building \\
\hline & Cowpea & Animal feed \\
\hline \multirow[t]{4}{*}{ Garundana } & Maize & Building, burning and animal feed \\
\hline & Millet and Sorghum & Burning and animal feed \\
\hline & Rice & Nil \\
\hline & Cowpea & Animal feed \\
\hline
\end{tabular}

Source: Author's Field Work, 2014 
Table 4: Quantity of Agricultural Crop Residue disposed by burning in the Study Area

\begin{tabular}{lcl}
\hline Community & $\begin{array}{l}\text { Estimated Quantity of Waste } \\
\text { Disposed by Burning (tons) }\end{array}$ & $\begin{array}{l}\text { Waste Disposed by Burning } \\
\text { Relation to other Community (\%) }\end{array}$ \\
\hline Miringa & 47 & 12.36 \\
Tum & 40 & 10.50 \\
Mandafuma & 28 & 7.35 \\
MainaHari & 43 & 11.29 \\
Buratai & 30 & 7.87 \\
Mandaragirau & 57 & 14.96 \\
Mangada & 37 & 9.71 \\
Kimba & 40 & 10.50 \\
Yamarkumi & 30 & 7.85 \\
Garundana & 29 & 7.61 \\
\hline Total & $\mathbf{3 8 1}$ & $\mathbf{1 0 0}$ \\
\hline
\end{tabular}

Source: Author's Field Work, 2014

\section{CONCLUSION}

An inventory of agricultural practices are not properly carried out, which can provide valuable information on the magnitude of agricultural crop residues generated quantity of residues disposed by burning as well as the estimated quantity of emissions from harmful pollutants released into the environment annually in Biu local government area of Borno State. Though, all the farmers associations contacted through focused group discussion confirmed that farmers still engaged in poor management of agricultural crop residues such as open burning, dumping, they reported that lack of awareness on human health hazard and environmental pollution is one of the major challenges facing the study area. Agricultural waste management should be integrated as part of the farm production System, so that it can be cared for as much as the farms product in order to avoid any environmental consequences resulting from poor waste management. This type of research should form part of the basis for agricultural residue reuse planning in our communities in order to minimize the negative perception agricultural crop residues. Encourage research and development projects for suitable technology in coping with the mounting agricultural waste management problems and enhance management efficiency through established academic and research institutes.

\section{Reference}

Adeoye, P. A., Adebayo, S. E. and Musa, J. J (2011) Agricultural post-harvest waste generation and management for selected crops in Minna, Niger State, North Central Nigeria. Journal of Applied Sciences in Environmental Sanitation Volume 6 Page 427-435

Andreae M O, Merlet P, (2001). Emissions of trace gases and aerosols from biomass burning, Global Biogeochemical Cycles, volume.15 (4): 955-966.

Bamidele JI, (1998). Disinfection of Sewage Sludge, a Microbial Aspect Proceeding of a C.E.C Workshop held in Zurich, May 11th 1988.

Costner, P., (2005). Estimating releases and prioritizing sources in the context of the Stockholm Convention. International POPs Elimination Project (IPEP). Website:<www.ipen.org>.

Kwaghe, P., Gwary, M., and Abdulsalam, R. a.-Y. (2011). Economic analysis of Agricultural waste managementamong farming household in Jere Local Government of Borno State, Nigeria. Journal of agricultural and biological science Volume.2 , 193-198.

John,Taiwo, and Oladeji, (2011) World Rural Observations.

Miller, D.W. (1980). Waste disposal effects on ground water. Berkeley, California. 
Mamman, M. \& Folorusho, J. O. (2016). Assessment of Open Burning of Agricultural Wastein Biu Local Government Area of Borno State, Nigeria. Advances in Social Sciences Research Journal, 3(6) 52-60.

Nilanthi, JGJ; Badara, J. and Patrick, A.H. (2010), Environmental Impact with Waste Disposal Practices in a Suburban Municipality in Sri Lanka. International Journal of Environment and Waste Management Volume.6, No.1, pp.107-16

Nix. J., (2002) Farm Management Pocketbook, 33rd Edition. Imperial College at Wye Onlinenigeria,(2003) Borno State, Physical Setting.Community Portal of Nigeria. Online Nigeria,www.onlinenigeria.com/Accessed $10 / 12 / 2010$.

Sabiiti EN, Bareeba F, Sporndly E, Tenywa JS, Ledin S, Ottabong E, Kyamanywa S, Ekbom B, Mugisha J and L Drake, (2005).Urban market garbage.A resource for sustainable crop/livestockproduction system and the environment in Uganda. A paper presented at the internationalconference, Wastes-The Social Context. Edmonton, Canada.

Taylor and Francis,(1971)West Africa, Volume 25, Part 1. Page285.

USEPA, (2000) Compilation of air pollutant emission factors, AP-42, 5th ed., 2.5: Openburning, http://www.epa. gov/ttn/chief/ap42/ch02.

UNSD, (1997) “Glossary of Environment Statistic” unstats.un.org

UNEP, and ISWA. (2002). Waste Management: Industry as a partner for sustainable development International solidwaste association and United Nation Environment Programme. 